Тихонов Алексей Константинович

Tikhonov Alexey Konstantinovich

кандидат юридических наук, доцент кафедры «Социально-правовые и гуманитарно-педагогические науки»

Саратовского государственного аграрного университета им. Н.И. Вавилова

\section{НОРМАТИВНО-ПРАВОВОЙ СТАТУС ПОТЕРПЕВШЕГО В УГОЛОВНОМ ПРОЦЕССЕ}

\section{Аннотация:}

В статье анализируется нормативно-правовое закрепление прав и обязанностей жертвы преступного посягательства в уголовном процессе. В ходе работы используются, в частности, сравнительно-исторический и государственно-правовой методы познания. Исследования в области прав, свобод и законных интересов личности свидетельствуют о необходимости коренным образом пересмотреть отношение к потерпевшему от преступления. Международное право, а также правовые системы многих государств исходят из требования видоизменить одностороннюю ориентацию лишь на раскрытие преступления. При такой направленности положение потерпевшего находится на периферии общественного внимания, а все процедуры и гарантии законности, гуманности, объективности главным образом относятся к подозреваемому, обвиняемому и др. Кроме того, безотлагательность рассмотрения статуса потерпевшего вызвана его низкой активностью в уголовном судопроизводстве. Однако именно этот участник в подавляющем большинстве случаев максимально заинтересован в изобличении преступников и их справедливом наказании. Еще одним недостатком в правовом статусе потерпевшего является то, что почти во всех нормативных формулировках, затрагивающих этот статус, наблюдается игнорирование ситуаций покушения на преступление.

Ключевые слова:

уголовное судопроизводство, потерпевший, жертва преступления, правосудие, правовой статус, личная безопасность, вред от преступления, моральный вред, приготовление к преступлению, покушение на преступление, квалификация, индивидуализация наказания.
PhD in Law, Associate Professor, Social, Legal, Education Sciences Saratov State Agrarian University

\section{LEGAL STATUS OF A VICTIM IN CRIMINAL PROCEEDINGS} and Humanities Department,
Summary: and duties of a victim of a criminal offence in criminal proceedings. The research is based on comparative historical and state legal methods of cognition. Studies in the field of rights, freedoms, and legitimate interests of the individual demonstrate the need to radically reconsider the attitude towards a victim of a crime. International law, as well as the legal systems of many states, proceeds from the requirements to modify a single-minded focus on crime solution. In this case, a victim is not in the spotlight while all procedures and guarantees of legality, humanity, and objectivity are mainly referred to the suspect or the accused. In addition, the status of a victim is to be considered because of his low involvement in criminal proceedings. However, it is a victim who is strongly interested in exposing criminals and their just punishment in the vast majority of cases. Another shortcoming in the legal status of a victim is that almost all legal descriptions of the victim's status neglect the attempts to commit a crime.
The paper analyzes the legal enshrinement of the rights
Keywords: criminal proceedings, victim, crime victim, justice, legal status, personal security, damage from crime, moral damage, preparation of a crime, attempt to commit a crime, qualification, individualization of punishment.

Действующий Уголовный кодекс РФ исходит из приоритета общечеловеческих ценностей и ставит главной задачей уголовно-правовую охрану личности. Учитывая названное основное положение, а также неразрывное единство уголовно-материальной и уголовно-процессуальной отраслей права, представляется необходимым остановиться на таком сложном правовом вопросе, как нормативное определение статуса потерпевшего. Эта задача настоятельно требует дальнейшего изучения и разрешения. Ведь такая потребность связана, в частности, с тем, что потерпевший, являясь одним из наиболее часто встречающихся участником уголовного судопроизводства, имеет самостоятельный интерес в процессе, фрактически противостоящий интересу подозреваемого, обвиняемого, подсудимого, осужденного (оправданного).

Исследования в области прав человека и гражданина свидетельствуют о необходимости коренным образом пересмотреть отношение к потерпевшему от преступления. Международное право и правовые системы многих государств также исходят из требования видоизменить одностороннюю ориентацию лишь на раскрытие преступления. При такой направленности (имеющей 
законодательную фриксацию и в нашей стране) положение потерпевшего находится на периферии общественного внимания, а все процедуры и гарантии законности, гуманности, объективности главным образом относятся к подозреваемому, обвиняемому и др. Потерпевший остается по существу лишь свидетелем преступления. Однако этим преступным деянием ему причинен вред, возмещение которого он вправе потребовать.

Кроме того, такая ситуация напрямую влияет на активность участия потерпевших от преступных посягательств в уголовном судопроизводстве. Она чрезвычайно низкая. Тем не менее именно этот участник в подавляющем большинстве случаев наиболее заинтересован в изобличении преступников и их справедливом наказании. Одной из главных причин пассивности выступает неспособность государства и его правоохранительных органов обеспечить личную безопасность участников процесса, в первую очередь пострадавших от преступлений. Это явление превращает в декларативную фикцию положения закона о праве потерпевшего на участие в уголовном преследовании (ст. 22 УПК РФ). Подобная фрактическая необеспеченность от внеправового воздействия на потерпевших исключает реализацию ими своего конституционного права на доступ к правосудию (ст. 52 Конституции РФ [1]).

Такое антиконституционное положение личности продолжает существовать, несмотря на то что в России для борьбы с этим явлением принят специальный Федеральный закон РФ от 20.08.2004 г. № 119-Ф3 «О государственной защите потерпевших, свидетелей и иных участников уголовного судопроизводства» [2]. Он вступил в силу 01.01.2005 г. и вместе с Уголовно-процессуальным кодексом РФ заложил законодательные основы системы государственной защиты названных участников судопроизводства.

Интересные критические мысли о правосудии и защите прав и законных интересов потерпевшего в уголовном судопроизводстве высказал американский юрист А.М. Дершовиц в работе «Правила игры в правосудие». В ней он особо подчеркивает, что «правосудие никому на самом деле не нужно». Ведь стороны, особенно в американском уголовном процессе, заинтересованы не в установлении истины и справедливом приговоре, в том числе защите жертв преступления, а лишь в «выигрыше» процесса [3].

В действующем российском законодательстве понятие потерпевшего наиболее полно представлено в Уголовно-процессуальном кодексе РФ. В нем к нему относятся и физическое лицо, которому преступлением причинен физический, имущественный, моральный вред, и юридическое лицо в случае причинения преступлением вреда его имуществу и деловой репутации (ч. 1 ст. 42 УПК РФ) [4].

В ранее действовавшем Уголовно-процессуальном кодексе РСФСР 1960 г. (ч. 1 ст. 53) к потерпевшим относились только физические лица, которым преступлением причинен моральный, физический или имущественный вред [5]. Однако по сравнению с еще более ранними законодательными актами это было законотворческим шагом вперед, поскольку сменяющие общегосударственные нормативные памятники (документы) по процедуре уголовного производства понемногу, но все же совершенствовали правовой статус потерпевшего по уголовным делам.

Так, в Уставе уголовного судопроизводства 1864 г. термин «потерпевший» упоминался неоднократно, правда, не всегда в совпадающих значениях. Например, это лицо, потерпевшее и «от преступных действий» (ст. 3), и «от преступления или проступка» (ст. 5, 6). В Уставе говорится и «о вознаграждении потерпевшего от преступления лица» (ст. 18), и о «потерпевших вред и убытки» (ст. 35), и о частных лицах, потерпевших «вред или убытки» (п. 1 ст. 42), и т. д. Тем не менее, исходя из текста Устава, можно сделать вывод, что во всех случаях законодатель того времени понимает под потерпевшим физическое лицо [6].

В Уголовно-процессуальных кодексах РСФСР 1922 и 1923 гг. правовое определение статуса потерпевшего также не было представлено в отдельной норме, но в них потерпевший уже упоминался как «понесший от преступного деяния вред и убытки» [7].

Нельзя не отметить, что при разработке ныне действующего УПК РФ (длившейся более 10 лет, в течение которых было подготовлено и опубликовано несколько вариантов проекта) предлагались различные как по форме, так и по существу определения понятия потерпевшего. Так, в одном из первых опубликованных проектов в ст. 48 говорилось: «При наличии доказательств, дающих основание полагать, что преступлением или общественно опасным деянием невменяемого гражданину причинен моральный, физический или имущественный вред, он признается потерпевшим» [8].

В другом проекте УПК РФ (ст. 34) потерпевший определяется как гражданин, который признается таковым «при наличии доказательств, указывающих на причинение ему непосредственно преступлением или запрещенным Уголовным кодексом Российской Федерации деянием невменяемого морального, физического или имущественного вреда» [9]. В ст. 31 еще одного проекта УПК сказано: «Потерпевшим признается лицо, которому преступлением или покушением на 
преступление или общественно опасным деянием невменяемого причинен моральный фризический или имущественный вред... Решение о признании потерпевшим принимается незамедлительно после установления события преступления, повлекшего причинение вреда, и не зависит от возраста, психического и физического состояния лица» [10].

В ст. 73 проекта Общей части УПК, подготовленного в ГПУ Президента РФ, сформулировано: «Потерпевшим признается фризическое лицо, в отношении которого имеются основания полагать, что ему запрещенным уголовным законом деянием непосредственно причинен моральный, фризический или имущественный вред. Потерпевшим признается также фризическое лицо, которому моральный, фризический или имущественный вред мог быть непосредственно причинен, если бы совершение запрещенного уголовным законом деяния было окончено» [11].

В ст. 46 одного из последних опубликованных проектов УПК отмечается: «Лицо в уголовном процессе признается потерпевшим при наличии оснований полагать, что ему непосредственно преступлением причинен моральный, фризический или имущественный вред (ч. 1). Лицо может признаваться потерпевшим и в случаях, когда вред ему нанесен запрещенным Уголовным кодексом Российской Федерации деянием, совершенным невменяемым (ч. 2). Потерпевшим может быть признано юридическое лицо, которому преступлением причинен моральный или материальный вред. В этом случае права и обязанности потерпевшего осуществляет представитель юридического лица (ч. 9)» [12].

Представляется, что приведенные определения по существу весьма сходны. Конструкции большинства представленных проектов правовых норм являются в значительной мере искусственными, вносящими ряд неясностей в понимание рассматриваемой проблемы.

В частности, исходя из буквального толкования предлагаемых первых трех редакций, приравниваются понятия потерпевшего от преступных действий вменяемого лица и потерпевшего от общественно опасных действий невменяемого, которые содержат признаки состава преступления, но без субъекта. Действительно, вред личности, пострадавшей от преступного посягательства, может быть нанесен любым лицом, в том числе невменяемым. Практически для пострадавшего не имеет принципиального значения, кем причинен ему вред - вменяемым или невменяемым, в результате умышленных действий или по неосторожности. Необходимость возмещения любого вреда пострадавшему от преступления сомнений не вызывает. Однако это не означает, что возмещение причиненного вреда невменяемым должно регулироваться одним и тем же порядком, что и вред, причиненный преступником (вменяемым лицом). Ведь с момента установления невменяемости начинает действовать особый порядок производства. Возникающие в связи с этим проблемы носят важный теоретический и сложный практический характер и, к сожалению, не нашли должного освещения и соответствующего разрешения. При этом решать их путем отождествления процессуальных вопросов возмещения вреда от общественно опасных действий невменяемого и от преступных действий вряд ли возможно.

Еще один неустранимый дефект критикуемых формулировок, в том числе используемых в УПК РФ, - отождествление понятия потерпевшего и лица, признанного потерпевшим. Представляется, что статус потерпевшего должен, как правило, возникать, исходя из факта причинения вреда, и основываться на соответствующем заявлении пострадавшего в правоохранительные органы.

Правоприменительная практика шла и идет по пути признания лица потерпевшим по уголовным делам и о приготовлении к преступлению, и о покушении на его совершение. Однако несовершенство понятия потерпевшего, данного, в частности, в ч. 1 ст. 42 УПК РФ (что неоднократно отмечалось), заключается и в том, что по его буквальному смыслу потерпевшим признается только лицо, которому преступлением причинен реальный ущерб. Иными словами, при отсутствии причинения такого вреда (поскольку преступление было пресечено на стадии покушения или приготовления), потерпевший отсутствует. Однако сам фракт покушения оказывает отнюдь не безобидное воздействие на психику лица. Поэтому в процессуальной защите нуждаются не только лица, которым преступлением причинен реальный ущерб, но также те, чьи интересы поставлены под угрозу преступным посягательством. Данный аспект, к сожалению, не учитывался и в большинстве упомянутых проектов УПК.

Наконец, недостатком почти всех рассматриваемых формулировок является игнорирование ситуаций покушения на преступление.

Однако приведенные определения указывают скорее на уголовно-материальные основания признания гражданина потерпевшим как пострадавшим от преступного посягательства. Действующий Уголовный кодекс РФ (равно как и предшествующий ему Уголовный кодекс РСФСР 1960 г.) хотя и содержит в ряде норм упоминания о потерпевшем, но самого понятия нигде не раскрывает. Тем не менее это необходимо и для правильной квалификации многих преступных деяний, и для индивидуализации наказания. 
На наш взгляд, было бы логично иметь базовое определение потерпевшего в уголовном законе (через вред, причиненный преступлением) и процессуальную интерпретацию понятия на этой основе. Ведь вред от преступления - одно из исходных понятий уголовного права.

Кроме того, в связи с рассматриваемыми вопросами необходимо также дать законодательное понятие морального вреда, поскольку по этому вопросу в теории высказаны различные суждения. На практике это приводит к различному истолкованию данной категории, создавая значительные трудности в правоприменительной деятельности. Конечно, любое преступление причиняет личности нравственные страдания хотя бы уже потому, что подтверждение противоправного посягательства или покушения на него вызывает у человека отрицательную психическую реакцию, нарушает нормальное психическое состояние. Поэтому под моральным вредом, причиненным преступным деянием, следует понимать нанесение ущерба чести, достоинству, репутации (в том числе деловой), доброму имени потерпевшего. Такой вред может наступать не только при клевете и оскорблении, но и, например, при похищении человека, нарушении тайны усыновления, заведомо незаконном аресте или задержании и т. п.

\section{Ссылки:}

1. Конституция РФ : принята на всенародном голосовании 12 дек. 1993 г. М., 2017.

2. О государственной защите потерпевших, свидетелей и иных участников уголовного судопроизводства [Электронный ресурс] : федер. закон от 20 авг. 2004 г. № 119-Ф3. Доступ из справ.-правовой системы «КонсультантПлюс».

3. Dershowitz A.M. The Best Defense. N. Y., 1983. P. XXI-XXII.

4. Уголовно-процессуальный кодекс РФ [Электронный ресурс] : федер. закон от 18 дек. 2001 г. № 174-Ф3 : в ред. от 19 февр. 2018 г. Доступ из справ.-правовой системы «КонсультантПлюс».

5. Уголовно-процессуальный кодекс РСФСР [Электронный ресурс] : утв. ВС РСФСР 27 окт. 1960 г. Доступ из справ.правовой системы «КонсультантПлюс».

6. Устав уголовного судопроизводства [Электронный ресурс] : от 20 нояб. 1864 г. URL: http://www.gumer.info/bibliotek_Buks/History/Article/ust_ugprav.php (дата обращения: 09.04.2018).

7. Уголовно-процессуальный кодекс РСФСР [Электронный ресурс] : от 25 мая 1922 г. URL: http://law.edu.ru/norm/norm.asp?normlD=1381074 (дата обращения: 09.04.2018) ; Уголовно-процессуальный кодекс PСФСР [Электронный ресурс] : от 15 февр. 1923 г. URL: http://www.lawmix.ru/docs_cccp/7955 (дата обращения: 09.04.2018)

8. Уголовно-процессуальное законодательство Союза ССР и РСФСР. Теоретическая модель / под ред. В.М. Савицкого. M., 1990. C. 69 .

9. Уголовно-процессуальный кодекс РФ : проект Министерства юстиции РФ. М., 1994. С. 27.

10. Уголовно-процессуальный кодекс РФ : проект НИИ проблем укрепления законности и правопорядка при Генеральной прокуратуре РФ. М., 1994. С. 18-19.

11. Проект Общей части Уголовно-процессуального кодекса РФ : проект Главного правового управления Президента РФ. М., 1994. С. 65.

12. Проект Уголовно-процессуального кодекса РФ // Юридический вестник. 1995. № 31. С. 5-6.

\section{References:}

Dershowitz, AM 1983, The Best Defense, New York, pp. XXI-XXII.

Draft of the General Part of the Code of Criminal Procedure of the Russian Federation: a draft of the Main Legal Department of the President of the Russian Federation 1994, Moscow, p. 65, (in Russian).

Regulations of Criminal Proceedings as of November 20, 1864 2018, viewed 09 April 2018, <http://www.gumer.info/bibliotek_Buks/History/Article/ust_ugprav.php>, (in Russian).

Savitsky, VM (ed.) 1990, The criminal procedure legislation of the USSR and the RSFSR. Theoretical model, Moscow, p. 69, (in Russian).

The Code of Criminal Procedure of the Russian Federation: a project of the Ministry of Justice of the Russian Federation 1994, Moscow, p. 27, (in Russian).

The Code of Criminal Procedure of the Russian Federation: a project of the Research Institute of Problems of Consolidation of Law and Order under the General Prosecutor's Office of the Russian Federation 1994, Moscow, pp. 18-19, (in Russian).

The Constitution of the Russian Federation adopted by popular vote on December 12, 19932017 , (in Russian).

The Criminal Procedure Code of the RSFSR as of February 15, 1923 2018, viewed 09 April 2018, $<$ http://www.lawmix.ru/docs cccp/7955>, (in Russian).

The Criminal Procedure Code of the RSFSR as of May 25, 1922 2018, viewed 09 April 2018, $<$ http://law.edu.ru/norm/norm.asp?normID=1381074>, (in Russian).

'The draft of the Code of Criminal Procedure of the Russian Federation' 1995, Yuridicheskiy vestnik, no. 31, pp. 5-6, (in Russian). 